\title{
SALMONELLOSIS IN RIO GRANDE DO SUL, BRAZIL, 1997 TO 1999
}

\author{
Suzana Costalunga ${ }^{1}$; Eduardo Cesar Tondo ${ }^{2 *}$ \\ 'Divisão de Vigilância Sanitária do Rio Grande do Sul, Porto Alegre, RS, Brasil. ${ }^{2}$ Departamento de Ciências dos Alimentos, \\ Instituto de Ciência e Tecnologia de Alimentos, Universidade Federal do Rio Grande do Sul, Porto Alegre, RS, Brasil.
}

Submitted: September 13, 2001; Returned to authors for corrections: March 15, 2002; Approved: December 05, 2002

\begin{abstract}
Salmonella spp. was the major cause of reported foodborne diseases in the last years in the State of Rio Grande do Sul, South of Brazil. Epidemiological data on salmonellosis, occurred in the period of 1997 to 1999 and supplied by the Division of Sanitary Surveillance (DVS/RS), were analysed according to the following factors: total number of confirmed outbreaks, number of people involved, outbreaks incidence according to the period of the year, age and sex of involved people, food vehicle, food storage conditions, local where the disease occurred, and possible causes of the outbreaks. The results indicated that 8217 people were involved, and 1557 had to be hospitalized. The highest number of outbreaks occurred during springtime and the principal age group affected was between 16 and 50 years. The most common food vehicle was salad prepared with homemade mayonnaise (42.45\%). The principal causes of salmonellosis were raw-materials not submitted to regulatory inspection $(22.92 \%)$, mainly eggs, and foods maintained at room temperature for more than 2 hours $(20.55 \%)$. The majority of the outbreaks occurred in private homes $(43.70 \%)$ and commercial food establishments (25.21\%).
\end{abstract}

Key words: Salmonella spp., foodborne disease, salmonellosis

\section{INTRODUCTION}

Salmonella spp. has been recognized worldwide as a common cause of foodborne gastroenteritis in humans $(13,15,25)$ and is also responsible for important economic losses (17).

In the last years, global surveillance data indicated that the number of salmonellosis has increased mainly associated with the consumption of raw or undercooked eggs, poultry, meat or dairy products $(11,12,20)$, demonstrating the importance of controlling this pathogen in food processes. One step towards the understanding of Salmonella spp. epidemiology is to improve surveillance services activities, especially related to the detection and reporting of outbreaks, followed by the organization and public information of the real occurrence of salmonellosis. These data are needed to perform risk assessment, set priorities, and decide on preventive measures to reduce foodborne diseases (14). In Brazil, we are at beginning of this complex organization, being very important to report regional salmonellosis data, when existent, from heath services.

The Division of Sanitary Surveillance of Rio Grande do Sul (DVS/RS) is composed by nineteen Regional Health Sections which investigate notified foodborne diseases in coordination with municipalities. Once an outbreak is notified, the suspected food is taken to the Central Laboratory (LACEN/RS) or accredited laboratories to be analyzed. Based on microbiological analysis and epidemiological data, annual reports for DVS/RS demonstrated Salmonella spp. as the major etiological agent responsible to foodborne diseases in Rio Grande do Sul in the last years (21). The objective of the present work was to analyze Salmonella spp. outbreaks occurred in Rio Grande do Sul, south of Brazil, during the period of 1997 to 1999.

\footnotetext{
* Corresponding author. Mailing address: Departamento de Ciência dos Alimentos, Instituto de Ciência e Tecnologia de Alimentos. Av. Bento Gonçalves, 9500 - Prédio 43212, Campus do Vale, Agronomia. 91540-000, Porto Alegre, RS, Brasil. Tel.: (+5551) 3316-7115, Fax: (+5551) 3316-7048. E-mail: tondo@ufrgs.br
} 


\section{MATERIALS AND METHODS}

Epidemiological data on outbreaks of salmonellosis occurred in the State of Rio Grande do Sul, South of Brazil, during the period between January 1997 to December 1999 were analyzed. Data were supplied by the Division of Sanitary Surveillance of Rio Grande do Sul (DVS/RS) based on final reports of epidemiological investigation of foodborne diseases carried out by inspectors of Regional Health Sections.

Outbreaks were investigated interviewing the involved people and, when possible, collecting samples of suspected foods and feces of ill persons and food handlers. The samples were analyzed for the presence of Salmonella spp. in Central Laboratory of Rio Grande do Sul (LACEN/RS) or in accredited laboratories close to the places of occurrence of outbreaks, using methods described by Food and Drug Administration (5).

\section{RESULTS}

Among 323 investigated outbreaks occurred in Rio Grande do Sul during the period from 1997 to 1999, 116 (35.7\%) were caused by Salmonella spp. In these outbreaks, 8217 people were involved, 2846 became ill, and 1557 were hospitalized. No death was registered (Table 1).

The 116 outbreaks of salmonellosis were confirmed by Attack Rate (No. of ill people/No. of involved people x 100), or/ and by the isolation of Salmonella spp. from the suspected food or feces of ill persons and food handlers.

The incidence of outbreaks of salmonellosis was higher in springtime (October, November, and December) $(n=48)$ than in the summertime (January, February, and March) $(n=38)$. The same was observed regarding the incidence of other etiological agents (eg. Staphylococcus aureus) of foodborne diseases in Rio Grande do Sul (data not shown). Table 2 shows that the most affected group classified by age was people between 16 and 50 years old $(64.31 \%)$, followed by children and teenagers from 6 to 15 years $(18.60 \%)$. The incidence of salmonellosis in male and female population was similar, $51.8 \%$ and $48.2 \%$, respectively.

Table 1. General data about outbreaks of Salmonella spp. in Rio Grande do Sul, 1997 to 1999.

\begin{tabular}{lrrrr}
\hline & 1997 & 1998 & 1999 & Total \\
\hline Confirmed outbreaks & 48 & 33 & 35 & 116 \\
Involved people & 2360 & 2854 & 3003 & 8217 \\
Ill people & 1073 & 960 & 813 & 2846 \\
Estimate ill people & 1775 & 2129 & 2471 & 6375 \\
Hospitalized people & 550 & 504 & 503 & 1557 \\
Deaths & 0 & 0 & 0 & 0 \\
\hline
\end{tabular}

A total of 139 food vehicles were responsible for the 116 investigated salmonellosis (Table 3), demonstrating the involvement of more than one food in some outbreaks.

Foods containing mayonnaise $(42.45 \%)$ and meats $(16.55 \%)$ were responsible for $58.9 \%$ of the incidents (Table 3 ).

The major incidence of outbreaks of salmonellosis occurred in private homes $(43.70 \%)$, followed by commercial food establishments (25.21\%). Clubs and associations, and community rooms were involved in $7.56 \%$ of the incidents (Table 4).

Data presented in Table 1 indicates that 48, 33, and 35 Salmonella spp. outbreaks occurred during the years 1997, 1998, and 1999, respectively. There is a small discrepancy between these data and those presented in Table 4 (48, 34, and 37 outbreaks, respectively) for the same period. This can be explained by the occurrence of the same outbreak in different places after a common food preparation.

Table 2. Age and sex of people involved in outbreaks of Salmonella spp. in Rio Grande do Sul State, Brasil, during the period of 1997 to 1999.

\begin{tabular}{crrrrc}
\hline Age (years) & 1997 & 1998 & 1999 & Total & $\%$ \\
\hline $0-1$ & 5 & 1 & 3 & 9 & $(0.31)$ \\
$2-5$ & 45 & 22 & 27 & 94 & $(3.25)$ \\
$6-15$ & 198 & 169 & 170 & 537 & $(18.60)$ \\
$16-50$ & 765 & 621 & 470 & 1856 & $(64.31)$ \\
$51-70$ & 91 & 109 & 119 & 319 & $(11.05)$ \\
$>70$ & 18 & 16 & 19 & 53 & $(1.83)$ \\
Unknown & 7 & 7 & 4 & 18 & $(0.62)$ \\
Sex & & & & & \\
Male & 506 & 443 & 415 & 1364 & $(51.8)$ \\
Female & 362 & 509 & 398 & 1269 & $(48.2)$ \\
\hline
\end{tabular}

Table 3. Food vehicles of outbreaks of Salmonella spp. in Rio Grande do Sul State, Brasil, during the period of 1997 to 1999.

\begin{tabular}{lrrrrr}
\hline \multirow{2}{*}{ Food vehicle } & \multicolumn{3}{c}{ Number of outbreaks } & \multicolumn{2}{c}{ Total } \\
\cline { 2 - 6 } & \multicolumn{1}{c}{1997} & 1998 & 1999 & \multicolumn{1}{c}{ 证 } & \multicolumn{1}{c}{$\%$} \\
\hline Salad* with mayonnaise & 24 & 19 & 16 & 59 & $(42.45)$ \\
Pastry products & 12 & 7 & 4 & 23 & $(16.55)$ \\
Meat and meat products & 8 & 7 & 8 & 23 & $(16.55)$ \\
Milk and dairy products & 2 & 1 & 1 & 4 & $(2.88)$ \\
Ice cream & - & 1 & - & 1 & $(0.72)$ \\
Bean & - & 1 & - & 1 & $(0.72)$ \\
River water & - & 1 & - & 1 & $(0.72)$ \\
Not identified & 10 & 7 & 10 & 27 & $(19.42)$ \\
\hline Total & 56 & 44 & 39 & 139 & 100 \\
\hline
\end{tabular}

* Salad of: potato, apple, paste, sweet cassava, vegetables, and others. 
Table 4. Place eaten of outbreaks of Salmonella spp. in Rio Grande do Sul State, Brasil, during the period of 1997 to 1999.

\begin{tabular}{lccccc}
\hline \multirow{2}{*}{\multicolumn{1}{c}{ Place }} & \multicolumn{3}{c}{ Number of outbreaks } & \multicolumn{2}{c}{ Total } \\
\cline { 2 - 6 } & 1997 & 1998 & 1999 & $\mathrm{n}$ & $\%$ \\
\hline $\begin{array}{l}\text { Private homes } \\
\text { Commercial food }\end{array}$ & 22 & 14 & 16 & 52 & $(43.70)$ \\
$\begin{array}{l}\text { establishments } \\
\text { Clubs and }\end{array}$ & 11 & 12 & 7 & 30 & $(25.21)$ \\
$\begin{array}{l}\text { associations } \\
\text { Community rooms }\end{array}$ & 5 & 2 & 2 & 9 & $(7.56)$ \\
Schools, nurseries, & 1 & 3 & 5 & 9 & $(7.56)$ \\
or asylums & 3 & 2 & 1 & 6 & $(5.04)$ \\
Hospitals & 2 & - & - & 2 & $(1.69)$ \\
Refectories & - & - & 1 & 1 & $(0.84)$ \\
Industrial kitchens & 1 & - & - & 1 & $(0.84)$ \\
Industries & 1 & - & - & 1 & $(0.84)$ \\
Others & 2 & 1 & 5 & 8 & $(6.72)$ \\
\hline Total & 48 & 34 & 37 & 119 & 100 \\
\hline
\end{tabular}

The principal factors that contributed to salmonellosis in Rio Grande do Sul during the analyzed period are presented in Table 5. Raw-materials without regulatory inspection (mainly eggs) were the major cause, being responsible for $22.92 \%$ of the outbreaks. Other causing factors were also detected: holding at ambient temperature for more than 2 hours (20.55\%); improper manipulation (13.04\%); inadequate refrigeration (12.65\%); poor hygiene of equipment and utensils (7.11\%), and crosscontamination $(5.53 \%)$.

\section{DISCUSSION}

It is known that only a small fraction of the foodborne diseases are reported to the sanitary authorities. Actually, probably less than $1 \%$ of the incidents are notified (14). Norling (18) reported that only $7 \%$ of the people involved in foodborne diseases in Sweden contacted the medical authorities, $3 \%$ contacted the suspected restaurant or similar places, and none contacted the environmental or public health authorities, demonstrating the low consumer awareness. Even in countries where surveillance services are very efficient, the real occurrence of foodborne diseases is not precisely known (10).

Based on reported cases, it is estimated that 4.6 million cases of salmonellosis occur each year in the United States (7). However, data from Brazil suggest that only 34.000 people per year become involved with salmonellosis (4), demonstrating huge differences between both estimates.

Few States in Brazil have surveillance services that organize the epidemiological data on foodborne diseases. Difficulties, such as low number of inspectors, economic difficulties, and improper systems of food poisoning notifications contribute to inadequate organization of data. The present work is a regional report on salmonellosis, which even incomplete, may contribute to the understanding of the agents, food vehicles, and contributing factors to the Brazilian foodborne diseases.

In the outbreaks of salmonellosis occurred in Rio Grande do Sul during the analyzed period, 2846 people became ill, and 1557 persons were hospitalized. Peresi et al. (19) demonstrated lower numbers of involved people in the State of São Paulo, where 295 persons were hospitalized among 906 involved people due to salmonellosis occurred between 1993 to 1997.

Table 5. Factors that contributed to the outbreaks of Salmonella spp. in Rio Grande do Sul State, Brasil, during 1997 to 1999.

\begin{tabular}{lrrrrr}
\hline \multirow{2}{*}{ Factors contributing to outbreak } & \multicolumn{3}{c}{ Number of outbreaks } & \multicolumn{2}{c}{ Total } \\
\cline { 2 - 6 } & 1997 & 1998 & 1999 & \multicolumn{1}{c}{$\%$} \\
\hline Raw material without regulatory inspection & 21 & 19 & 18 & 58 & $(22.92)$ \\
Holding at ambient temperature for more than 2 hours & 23 & 13 & 16 & 52 & $(20.55)$ \\
Improper manipulation & 13 & 8 & 12 & 33 & $(13.04)$ \\
Inadequate refrigeration & 19 & 8 & 5 & 32 & $(12.65)$ \\
Poor hygiene of equipment and utensils & 5 & 6 & 7 & 18 & $(7.11)$ \\
Cross-contamination & 3 & 4 & 7 & 14 & $(5.53)$ \\
Contamination by infected food handler & 3 & 2 & 1 & 6 & $(2.37)$ \\
Inadequate hot holding & 3 & 2 & & 5 & $(1.98)$ \\
Inadequate cooking & 1 & 1 & 3 & 5 & $(1.98)$ \\
Ingestion of contaminated water & - & 1 & 3 & 4 & $(1.58)$ \\
Improper reheating & - & - & 1 & 1 & $(0.40)$ \\
Improper place of food processing & - & 1 & - & 1 & $(0.40)$ \\
Use of wood utensils & 1 & - & - & 1 & $(0.40)$ \\
Unknown & 11 & 8 & 4 & 23 & $(9.09)$ \\
\hline Total & 103 & 73 & 77 & 253 & 100 \\
\hline
\end{tabular}




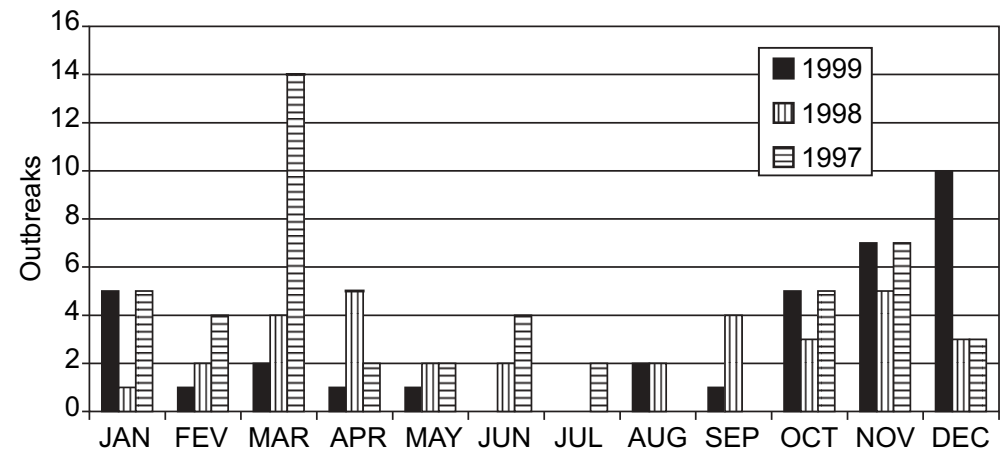

Figure 1. Monthly occurrence of outbreaks of Salmonella spp. in Rio Grande do Sul State, Brazil, in the period of 1997 to 1999.

In Rio Grande do Sul, Salmonella spp. was responsible for $35 \%$ of the outbreaks that occurred between 1997 to 1999. Similar results were reported in different places of the world. Salmonella spp. have accounted for $45 \%$ of foodborne disease outbreaks of known etiology during 1973 to 1987 in the United States (7). Higher percentages were observed by Scuderi et al. (23) in Italy during 1991 to 1994, when Salmonella spp. was responsible for $81 \%$ of the outbreaks, being $S$. Enteritidis related to $34 \%$ of them. Machado and Bernardo (16) also reported that since 1984, the same microorganism has been the most frequent cause of human salmonelosis in Portugal. All these findings confirm the importance of this etiological agent concerning public health issues.

In relation to the time of the year and the incidence of salmonellosis, Binsztein et al. (1), and Cliver (3) demonstrated higher incidence of salmonellosis in Argentina, and USA, respectively, in summertime. In opposite, ours findings showed that the highest number of outbreaks of salmonellosis in Rio Grande do Sul occurred in springtime. According to the Surveillance Service, this can be explained by the more frequent food handlers negligence, especially inadequate food refrigeration, during seasons with mild temperatures. Such carelessness is easily observed during winter and is prolonged into spring when temperature in Rio Grande do Sul is frequently lower than $10^{\circ} \mathrm{C}$. It is important to emphasize that the higher incidence of outbreaks in springtime also occurred with other etiological agents of foodborne diseases, confirming the negligence in general good manufacturing practices mainly in this season.

Based on Food and Drug Administration (6), all ages are susceptible to Salmonella spp., but the symptoms are more severe to the elderly and children (24). In this study, Salmonella spp. outbreaks were more frequent in people with ages between 16 and 50 years (64.31\% of the cases).

As shown in the present study, many kinds of foods were vehicle of Salmonella spp. by salads prepared with homemade mayonnaise were the major foods involved with the incidents. Other important vehicles were meats, meat products and pastry products. Many authors outlined the consumption of raw eggs and egg products as the principal cause to the increase of Salmonella gastroenteritis worldwide $(2,8,9,19,22)$, Nevertheless, meats, milk and dairy products have been involved with many outbreaks (11).

In the last years, the number of outbreaks involving eggs have been reduced in Rio Grande do Sul. This can be attributed to the less utilization of homemade mayonnaise and to the development of a program to control the quality of raw eggs, elaborated by the Center of Sanitary Surveillance (CVS) of Porto Alegre city, DVS/RS, Agriculture Ministry, and Associação Gaúcha de Avicultores (ASGAV). Due to this program, since 1996, all egg producer establishments should indicate the shelf-life of eggs and confirm the regulatory inspection.

In a high percentage of the salmonellosis outbreaks (19.42\% - Table 3), the responsible food could not be identified, showing that the sanitary authorities have difficulties with sample collection, reports from sick people, and also with unreliable information during the epidemiological investigation.

With relation to location and factors contributing to the outbreaks, the majority of them occurred in private homes and commercial food establishments. The main causes were holding of foods for more than 2 hours at room temperature or utilization of non inspected raw-materials (especially eggs). Similar data were presented by Caffer and Eiguer (2) and by Lindqvist et al. (14) who demonstrated that $94 \%$ of the Salmonella outbreaks in Argentina and $80 \%$ of the outbreaks in Sweden, respectively, occurred in residences or food shops.

Surveillance of foodborne diseases is becoming more important in the control and prevention of food pathogens. However, the quality of reported data by the Surveillance Services needs to be improved in order to originate reliable conclusions and appropriate decisions. In addition, it is important to implement Good Manufacturing Practices, and the principles of the Hazard Analysis of Critical Control Point (HACCP) system to decrease the impact of foodborne diseases.

\section{ACKNOWLEDGMENTS}

We would like to thank the staff of Water and Food Microbiology Laboratory of LACEN/RS, and especially the Veterinarians Dr. Denise Maria da Silva Figueiredo and Dr. Clair Rejane Dutra, from the Health Secretary of Rio Grande do Sul, who have worked intensively to improve the regional Surveillance Service in the last years. 


\section{RESUMO}

\section{Salmoneloses no Rio Grande do Sul, Brasil, de 1997 a 1999}

Salmonella spp. foi a principal causa de doenças transmitidas por alimentos nos últimos anos no estado do Rio Grande do Sul, sul do Brasil. Foram avaliados dados epidemiológicos de salmoneloses ocorridas durante o período de 1997 a 1999 fornecidos pela Divisão de Vigilância Sanitária do Rio Grande do Sul. Os seguintes fatores foram investigados: número total de surtos confirmados, número de pessoas envolvidas, incidência dos surtos de acordo com a estação do ano, idade e sexo das pessoas envolvidas, principais alimentos envolvidos, local de armazenagem dos alimentos envolvidos e local de ocorrência dos surtos e suas causas prováveis. Os resultados demonstraram 8217 pessoas envolvidas, das quais 1557 foram hospitalizadas. $\mathrm{O}$ maior número de surtos ocorreu durante a primavera, enquanto as pessoas na faixa etária de 16 a 50 anos foram mais frequentemente afetadas. $\mathrm{O}$ alimento mais comumente relacionado aos surtos foi a maionese caseira $(42,45 \%)$, enquanto as principais causas das salmoneloses foram a utilização de matéria-prima sem inspeção $(22,92 \%)$, na grande maioria ovos, e alimentos mantidos à temperatura ambiente por mais de 2 horas $(20,55 \%)$. A maioria dos surtos ocorreu dentro de residências $(43,70 \%)$ e estabelecimentos comerciais $(25,21 \%)$.

Palavras-chave: Salmonella spp., surtos de doenças transmitidas por alimentos, salmonelose.

\section{REFERENCES}

1. Binsztein, N.; Eiguer, T.; D'empaire, M. Epidemia de salmonellosis em Buenos Aires y sus alrededores. Medicina, Buenos Aires, 42: 161-167. 1982.

2. Caffer, M.I.; Eiguer, T. Salmonella enteritidis in Argentina. Int. J. Food Microbiol., 21: 15-19, 1994.

3. Cliver, D.O. Foodborne diseases. San Diego: Academic Press, 1990, Academic Press. Inc. San Diego, 1990, 191p.

4. Flores, M.L.; Silva, J.H.S.; Nascimento, V.P.; Kader, I.I.T.A.; Santos, L.R.; Pontes, A.P.; Salle, C.T.P.; Lopes, R.F.F. Detecção de Salmonella sp. em ovos de galinhas através da reação em cadeia pela polimerasePCR. Higiene Alimentar, 15: 63-68, 2001.

5. Food and Drug Administration (FDA). Bacteriological Analytical Manual. 8. ed. Washington, 1995, 1050 p.

6. Food and Drug Administration (FDA). Center for Food Safety \& Applied Nutrition Foodborne pathogenic microorganisms and natural toxins handbook. http://vm.cfsan.fda.gov./.../chap 1 html> Acess 24/03/2001

7. Hao, Y.Y.; Scouten, A.J.; Brackett, R.E. Cheesecake: a potential vehicle for salmonellosis? J. Food. Protect., 62: 26-29, 1999.

8. Hobbs, B.C.; Roberts, D. Toxinfecções e controle higienico-sanitário de Alimentos, Varella, São Paulo, 1999. 425 p.

9. Humphrey, T.J. Contamination of egg shell and contents with Salmonella enteritidis: a review. Int. J. Food Microbiol, 21: 31-40, 1994.

10. Jay, J. Modern food microbiology. 5. ed. Chapman e Hall, New York, 1996, 516 p.

11. Khakhria, R.; Woodward, D.; Johnson, W. M.; Poppe, C. Salmonella isolated from humans, animals, and other sources in Canada, 198392. Epidemiol. Infect., 119: 15-23, 1997.

12. Laconha, I.; López-Molina, N.; Rementeria, A.; Audicana, A. Perales, I.; Garaizar. Phage typing combined with pulsed-field gel electrophoresis and random amplified polymorphic DNA increases discrimination in the epidemiological analysis of Salmonella enteritidis strains. Int. J. Food Microbiol., 40: 27-34, 1998.

13. Laconha, I.; Baggesen, D.L.; Rementeria, A.; Garaizar, J. Genotypic characterization by PFGE of Salmonella enterica serotype Enteritidis phage types1,4,6, and 8 isolated from animal and human sources in three European countries. Vet. Microbiol., 75: 155-165, 2000.

14. Lindqvist, R.; Andersson, Y.; Jong, B.; Norberg, P. A summary of reported foodborne disease incidents in Sweden, 1992 to 1997. J. Food Protec., 63:1315-1320, 2000.

15. Lopalco, P.L.; Germinario, C.; Di Martino, V.; Frisoli, L.; Pagano, A.; Quarto, M.; Barbuti, S. Epidemiologic study and cost analysis of an Salmonella Enteritidis epidemic. Ann Ig, 12: 279-285, 2000.

16. Machado, J.; Bernardo, F. Prevalence of Salmonella in chicken carcasses in Portugal. J. Appl. Bacteriol., 69: 477-480, 1990.

17. Miyamoto, T.; Horie, T.; Baba, E.; Sasai, K.; Fukata, T. Arakawa, A. Salmonella penetration through egg shell associated with freshness of laid eggs and refrigeration. J. Food Protec., 61: 350-353, 1998.

18. Norling, B. Food poisoning in Sweden: reports of a field survey. National Food Administration, Uppsala, Sweden. Report No 41/94.

19. Peresi, J.T.M.; Almeida, I.A.Z.C.; Lima, S.I.; Marques, D.F. Rodrigues, E.C.A.; Fernandes, S.A.; Gelli, D.S.; Irino, K. Surtos de enfermidades transmitidas por alimentos causados por Salmonella Enteritidis. Res. Saúde Pública, 32: 477-483, 1998.

20. Pinto, S.A. Aspectos sanitários da salmonelose como uma zoonose. Higiene Alimentar, 14: 32 , 2000.

21. Rio Grande do Sul. Secretaria Estadual da Saúde. Divisão de Vigilância Sanitária. Relatório anuais de DTA. Porto Alegre, 2001 (não paginada)

22. Santos, D.M.S.; Junior, A.B.; Fernandes, S.A.; Tavechio, A.T.; Amaral, L.A. Salmonella em carcaças de frango congeladas. Pesq. Vet. Bras., 20: 39-42, 2000.

23. Scuderi, G.; Fantasia, M.; Filetici, E.; Anastasio, M.P. Foodborne outbreaks caused by Salmonella in Italy, 1991-1994. Epidemiol. Infect., 116: 257-265, 1996.

24. Saeed, A.M. Salmonella enterica Serovar Enteritidis in humans and animals. Epidemiology, pathogenesis, and control. Iowa State University Press, Ames, 1999. 443p.

25. Tsen, H.Y.; Hu, H.H.; Lin, J.S.; Huang, C.H.; Wang, T.K. Analysis of Salmonella typhimurium isolates from food-poisoning cases by molecular subtyping methods. Food Microbiol., 17: 143-152, 2000 . 